\title{
Antimicrobial activity of essential oils from Lippia alba, Lippia sidoides, Cymbopogon citrates, Plectranthus amboinicus, and Cinnamomum zeylanicum against Mycobacterium tuberculosis
}

\author{
Aquiles Paulino Peres $\operatorname{Mota}^{1} \odot$ João Carlos Pinheiro Dantas ${ }^{1} \odot$ Cristiane $^{-}$Cunha $_{\text {Frota }}{ }^{*} \odot$
}

${ }^{1}$ Laboratório de Micobactérias, Departamento de Patologia e Medicina Legal, Faculdade de Medicina, Universidade Federal do Ceará (UFC), Rodolfo Teófilo, 60430-270, Fortaleza, CE, Brasil. E-mail: cristianefrota71@gmail.com. "Corresponding author.

ABSTRACT: The rise in cases of antibiotic-resistant Mycobacterium tuberculosis has become a major obstacle to the effective control of tuberculosis (TB) worldwide. Essential oils (EO) are complex mixtures that may contain between 20 and 60 components, with two or three major compounds at relatively high concentrations (20-70\%) that are responsible for their pharmacological properties. The objective of this study was to assess the antimicrobial activity of the EOs, bushy lippia (Lippia alba), rosemary pepper (Lippia sidoides), lemon grass (Cymbopogon citratus), Mexican mint or Indian borage (Plectranthus amboinicus), and true cinnamon (Cinnamomum zeylanicum), against Mycobacterium tuberculosis H37Rv. Chemical characterization of the EOs was performed by gas chromatography coupled to mass spectrometry. The minimum inhibitory concentration (MIC) was determined by the microdilution-based resazurin microtiter assay. Four EOs were able to inhibit the growth of M. tuberculosis, with MICs of $286.5 \pm 130.2 \mu \mathrm{g} / \mathrm{mL}$ (C. zeylanicum), $299.5 \pm 117.2 \mu \mathrm{g} / \mathrm{mL}$ (L. sidoides), 351.6 $\pm 39.06 \mu \mathrm{g} / \mathrm{mL}$ (P. amboinicus), and $1,250 \mu \mathrm{g} / \mathrm{mL}$ (C. citratus). Only the EO of L. alba showed no antimycobacterial activity at the tested concentrations, with an MIC greater than $1,250 \mu \mathrm{g} / \mathrm{mL}$. Results of this study suggested that C. zeylanicum, L. sidoides, and P. amboinicus could be important sources of bactericidal compounds against M. tuberculosis and require further investigation. The activity against M. tuberculosis of these three EOs has not been reported previously. The results show the high potential of the tested antimycobacterial EOs, making them a promising alternative for TB treatment. This data also confirms the importance of bioprospecting studies for active substances with antimycobacterial activity, which are still scarce.

Key words: anti-bacterial agent, essential oils, Mycobacterium tuberculosis, Lippia alba, Lippia sidoides, Cymbopogon citrates, Plectranthus amboinicus, Cinnamomum zeylanicum.

Atividade antimicrobiana de óleos essenciais de Lippia alba, Lippia sidoides, Cymbopogon citrates, Plectranthus amboinicus, e Cinnamomum zeylanicum em Mycobacterium tuberculosis

RESUMO: O aumento no número de casos de Mycobacterium tuberculosis resistentes tem se tornado um grande obstáculo no controle efetivo da tuberculose (TB) mundialmente. Os óleos essenciais (OE), que são misturas complexas que podem conter entre 20 a 60 componentes, apresentam dois ou três compostos principais, em concentrações relativamente elevadas, 20 a $70 \%$, que são responsáveis pelas suas propriedades farmacológicas. $O$ objetivo deste estudo foi avaliar a atividade antimicobacteriana dos seguintes óleos essenciais (OEs) em Mycobacterium tuberculosis H37Rv: erva-cidreira (Lippia alba), alecrim-pimenta (Lippia sidoides), capim-limão (Cymbopogon citratus), orégano (Plectranthus amboinicus) e canela (Cinnamomum zeylanicum). A caracterização química dos OEs foi realizada por cromatografia gasosa acoplada a espectrometria de massa. A Concentração Inibitória Mínima (CIM) foi determinada pela técnica de microdiluição

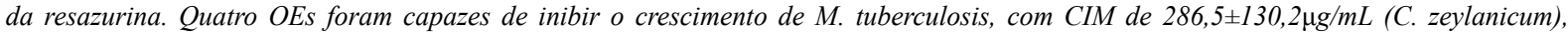

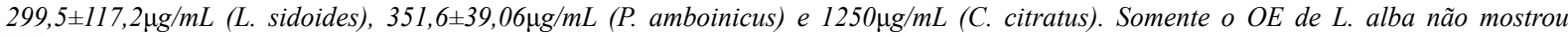
atividade antimicobacteriana nas conscentrações testadas, considerando CIM maiores que $1250 \mu \mathrm{g} / \mathrm{mL}$. Os resultados deste estudo sugerem que L. sidoides, C. zeylanicum e P. amboinicus podem ser fontes importantes de compostos bactericidas contra M. tuberculosis e prováveis candidatos a serem investigados. A atividade contra M. tuberculosis desses três OEs não foi relatada em estudos anteriores. Os resultados mostram o elevado potencial antimicobacteriano dos OEs analisados, fazendo deles uma alternativa promissora para o tratamento da TB. Os resultados obtidos demonstraram a importância de pesquisas para bioprospecção de substâncias ativas com ação antimicobacteriana, que ainda são escassas.

Palavras-chave: agente antibacteriano, óleos essenciais, Mycobacterium tuberculosis, Lippia alba, Lippia sidoides, Cymbopogon citrates, Plectranthus amboinicus, Cinnamomum zeylanicum.

\section{INTRODUCTION}

Tuberculosis (TB) is one of the oldest known infectious diseases, and the World Health
Organization (WHO) declared it a public health emergency 20 years ago. It is currently the second leading cause of death due to infectious disease, with 10.4 million new cases worldwide in 2016 
and approximately 2.1 million deaths, of which 1.7 million were exclusively due to $\mathrm{TB}$ and 0.4 million due to HIV/TB co-infection (WHO, 2017).

One of the main factors that have hindered TB control worldwide is the increasing number of multidrug-resistant $M$. tuberculosis (MR-TB) cases, defined as being resistant to isoniazid and rifampicin. The WHO estimated that there were 600,000 new cases of MDR-TB in 2016, leading to approximately 190,000 deaths (WHO, 2017).

Although, a large number of drugs have been released in the last three decades by the pharmaceutical industries, bacillus resistance has hindered the development of new drugs, thereby reducing therapeutic options (MIGLIORI \& SOTGIU, 2010). One of the main characteristics of $M$. tuberculosis is its complex cell wall with high lipid content; approximately $60 \%$ of its composition consists of long-chain mycolic acids (FORRELLAD et al., 2013).

Medicinal plants were one of the first therapeutic resources available for human health maintenance and promotion and they continue to be a valuable source of natural products (NASCIMENTO et al., 2000). Discovery and development of new drugs are important, particularly for the treatment of cancer and infectious diseases; moreover, $60 \%$ and $75 \%$, respectively, of the currently used drugs for cancer and infectious diseases are directly or indirectly derived from natural sources (NEWMAN et al., 2003).

Medicinal plants produce secondary metabolites, such as essential oils (EOs), which are complex mixtures that may contain between 20 and 60 components at very different concentrations. Generally, these EOs are present as variable mixtures of primarily terpenoids, especially monoterpenes and sesquiterpenes; although, diterpenes may also be present. In addition, they contain a wide range of secondary metabolites that can inhibit or slow the growth of microorganisms (SWAMY et al., 2016). Therefore, it is believed that medicinal plants are excellent alternatives for discovering new drugs, and as novel alternatives for TB treatment, they provide an extensive source for bioprospecting for active substances. Several natural products have already been described as exhibiting potent antimycobacterial activity against MDR-MTB, including bisbenzylisoquinoline alkaloids (SURERAM et al., 2012) and the natural tetramic acid vermelhotin from fungi (GANIHIGAMA et al., 2015).

Bioactivity of extracts and EOs of Lippia alba (MACHADO et al., 2014), Lippia sidoides (FREIRES et al., 2015a), Plectranthus amboinicus (VASCONCELOS et al., 2017), and Cinnamomum zeylanicum (ANDRADE et al., 2012;
WIWATTANARATTANABUT et al., 2017) has been evaluated with promising results in assays against gram-negative and gram-positive bacteria. In previous studies, hexane extracts of Cymbopogon citratus (MOHAMAD et al., 2018) and compounds of $C$. zeylanicum (ANDRADE-OCHOA et al., 2015) were reported to exhibit promising anti-TB activity against M. tuberculosis H37Rv, supporting their traditional uses in the treatment of TB. As part of continuous research to discover new potent and cheaper antiTB agents, we investigated the antimycobacterial activity of EOs extracted from L. alba (LalbEO), $L$. sidoides (LsidEO), C. citratus (CcitEO), P. amboinicus (PambEO) and C. zeylanicum (CzeyEO) against the wild type $M$. tuberculosis $\mathrm{H} 37 \mathrm{Rv}$ strain, since they are traditionally used as remedies to cure various diseases. These five plants are widely distributed in tropical countries and are commonly cultivated as garden herbs for use in cooking and for medicinal purposes.

\section{MATERIALS AND METHODS}

\section{Study location and plant material}

The study was conducted in Fortaleza, the state capital of Ceará, in northeastern Brazil, $412 \mathrm{~km}$ from the equator. It has a typical tropical climate with temperature varying during the year from $24.6^{\circ} \mathrm{C}$ to $30.7^{\circ} \mathrm{C}$ (INMET, 2018). Leaves of the bushy lippia [L. alba (Verbenaceae)], rosemary pepper [L. sidoides (Verbenaceae)], lemon grass [C. citratus (Poaceae)], and Mexican mint or Indian borage $[P$. amboinicus (Lamiaceae)] species were collected between eight and ten o'clock in the morning from the garden of Medicinal Plants Francisco José de Abreu Matos, Universidade Federal do Ceará. The bark of true cinnamon $[C$. zeylanicum (Lauraceae)] species was acquired at the local market for medicinal plants in Fortaleza.

Plant samples were deposited at the Prisco Bezerra Herbarium, at the Department of Biology, under the following identifications: EAC55065 [Lippia alba (Mill) NE Brown.], EAC54125 (Lippia sidoides Cham.), EAC54263 [Cymbopogon citratus (DC). Stapf.], and EAC54393 [Plectranthus amboinicus (Lour.) Spreng]. Since there was insufficient plant material (flowers, bark, and roots) of C. zeylanicum species to identify the species, it was not possible to deposit the sample.

\section{Extraction of EOs}

In order to extract the plant oil, fresh leaves and the cinnamon bark were subjected to hydrodistillation using a Clevenger-type apparatus for up to 2 hours, as recommended by the British Pharmacopeia. The procedure was repeated three times 
using $50 \mathrm{~g}$ of the material each time. After drying the EO using anhydrous sodium sulfate, it was kept in a sealed amber bottle at $4^{\circ} \mathrm{C}$ until gas chromatography/mass spectrometry (GC/MS) analysis and further analysis (CRAVEIRO et al., 1976).

\section{Chemical analysis of the EOs}

The analysis of all EOs was performed using a Gas Chromatographic System equipped with a PE-5 column $(30 \mathrm{~m} \times 0.25 \mathrm{~mm}$ i.d., $0.25 \mu \mathrm{m}$ film thickness $)$ and a Mass Spectrometer as detector (GC/MS - QP2010 SE, Shimadzu do Brasil, Barueri, Brazil). The carrier gas was helium, and the flow rate was $1 \mathrm{~mL} / \mathrm{min}$. For the GC-FID analysis, the temperature was increased from $50^{\circ} \mathrm{C}$ to $280^{\circ} \mathrm{C}$ at $1^{\circ} \mathrm{C} / \mathrm{min}$. The injector and detector temperature were set at $250^{\circ} \mathrm{C}$ (ADAMS, 2001).

The highest extraction yield was observed for the LsidEO $(0.68 \%)$, followed by LalbEO $(0.49 \%)$, CcitEO (0.30\%), and CzeyEO (0.13\%), whereas the lowest extraction yield was observed for PambEO (0.009\%).

Determination of minimum inhibitory concentration (MIC) by resazurin microtiter assay

The assays to determine the Minimum Inhibitory Concentration (MIC) were performed by the Resazurin Microtiter Assay method (REMA), according to previous studies (FRANZBLAU et al., 1998; PALOMINO et al., 2002).

Initially, the $M$. tuberculosis $\mathrm{H} 37 \mathrm{Rv}$ inoculum, (donated by Dr CC Frota, Mycobacteria Laboratory of the Universidade Federal do Ceará), was prepared from young cultures, previously cultivated for 3 weeks in Löwenstein-Jensen (LJ) medium. The cultures were resuspended in Middlebrook $7 \mathrm{H} 9$ broth supplemented with ADC to reach a turbidity equivalent to that of McFarland's nephelometer No. 1 standard. Then, to obtain the test inoculum, the suspension was diluted at 1:10 with the same culture medium immediately before use.

The REMA microdilution method was performed in sterile 96-well microplates. Each EO $(5 \mathrm{mg} / \mathrm{mL}$ in $1 \%$ Tween-80) was tested in duplicate on different days. In addition, on each plate, each EO was assayed in sextuplicates. All solutions were sterilized using a $0.22 \mu \mathrm{m}$ diameter filter.

A total of $100 \mu \mathrm{L}$ of $7 \mathrm{H} 9-\mathrm{ADC}$ broth was added into all central wells of the microplate. The outer perimeter wells received $300 \mu \mathrm{L}$ of sterile distilled water. Subsequently, serial two-fold dilutions of these solutions were prepared using $100 \mu$ l of each EO, up to $1 / 64$ of its initial concentration. Thus, the range of concentrations tested was $1.250-19.53 \mu \mathrm{g} / \mathrm{mL}$.
In the microplate, wells were also tested with a positive control (without EO), negative growth control (without inoculation), and mycobacterial susceptibility control $[1 \mu \mathrm{g} / \mathrm{mL}$ rifampicin in dimethyl sulfoxide (SINGH et al., 2012)]. One hundred microliters of the inoculum solution was added to all plate wells, except to the negative control. Finally, the plates were sealed and incubated at $37^{\circ} \mathrm{C}$.

After 7 days of incubation, $30 \mu \mathrm{L}$ of resazurin solution was added (1:1 solution of resazurin $0.02 \%$ and $10 \%$ Tween- 80 ) to all plate wells, except wells containing water. Then, in order to perform the reading of the reaction, the microplate was incubated for an additional 24 hours. Wells with a well-defined pink color were scored as positive for growth. The MIC was defined as the lowest EO concentration able to inhibit mycobacterial growth, observed through the maintenance of the resazurin blue color.

\section{Statistical analysis}

The MIC values were calculated from the arithmetic mean of the sextuplicates on each plate and the arithmetic mean of the duplicates on different plates. Results of the MIC values were computed on GraphPad Prism $7^{\circledR}$ software, and expressed as mean \pm SEM (standard error of mean).

\section{RESULTS AND DISCUSSION}

EOs are complex mixtures of compounds with biological activities that are mainly attributed to their major compounds. However, all their components, including those at lower concentrations, can interact with each other resulting in a synergistic effect, potentiating the EO activity, or creating an antagonistic effect, reducing its action (ANDRADE-OCHOA et al., 2015).

The yield of extraction to obtain the EO by hydrodistillation from the leaves of the bushy lippia (L. alba), rosemary pepper (L. sidoides), lemon grass (C. citratus), and Mexican mint (P. amboinicus), and from the bark of cinnamon $(C$. zeylanicum) were similar to or lower than those reported in the literature (PARANAGAMA et al., 2001; SCHUCK et al., 2001; NUNES et al., 2005; TAVARES et al., 2005; RODRIGUES et al., 2013). Several factors affect the yield, including the time of the harvest, where the yield is higher in the morning, and tends to decrease throughout the day. The increasing of temperature directly influences the yield of the extraction (MIRANDA et al., 2013). In addition, the relative concentrations of the constituents of each EO do not depend only on the plant species. Among various factors influencing chemical composition, the most important are the part of the plant 
used; the stage of development of the plant; the climatic and growth conditions, such as temperature, soil, and fertilization; and the distillation and storage conditions (OLADIMEJI et al., 2001). In addition, the low yield of the extraction of EO from cinnamon was due to the formation of hidrolate, a mixture of water and oil; the EO of cinnamon had a density of $1,050 \mathrm{~g} / \mathrm{m}$, a value higher than that of water, a phenomenon described in a previous reported study (MENDES, 2011).

The main compounds of each of the five EOs are shown in table 1. The EO of the bushy lippia (LalbEO) contained geranial (40.1\%) and neral (30.5\%) compounds, which together are called citral (70.6\%), and $\alpha$-limonene $(11.6 \%)$ as its major components, similar results to those reported in the study by
TAVARES et al. (TAVARES et al., 2005). The main compounds reported in the LsidEO (rosemary pepper) were caryophyllene $(30.2 \%), p$-cymene $(28.7 \%)$, $\gamma$-terpinene $(9.8 \%)$, eucalyptol $(7.5 \%)$, and thymol $(6.3 \%)$. However, most studies on plants of the same native species in northeastern Brazil demonstrated the presence of thymol as the main constituent of its EO (MARCHESE et al., 2016). The chemical constituents of CcitEO (lemon grass) were citral 80.7\% (45.4 and $35.3 \%$ of geranial and neral, respectively) and myrcene (13.4\%), a result similar to the concentrations reported in a study using reverse phase high performance liquid chromatography (GAONKAR et al., 2016). The PambEO (Mexican mint) contained thymol (61.5\%), p-cymene (11.2\%), and $\gamma$-terpinene compounds $(10.3 \%)$

Table 1 - Frequency of the concentration of the major molecular compounds identified in the essential oils of bushy lippia, rosemary pepper, lemon grass, mexican mint and cinnamon using gas chromatography mass spectrometry (GC-MS).

\begin{tabular}{|c|c|c|c|c|c|}
\hline \multirow[b]{2}{*}{ Compound (\%) } & Bushy lippia & Rosemary pepper & Lemon grass & Mexican mint & Cinnamon \\
\hline & (Lippia alba) & (Lippia sidoides) & $\begin{array}{l}\text { (Cymbopogon } \\
\text { citratus) }\end{array}$ & $\begin{array}{c}\text { (Plectranthus } \\
\text { amboinicus) }\end{array}$ & $\begin{array}{c}\text { (Cinnamomum } \\
\text { zeylanicum) }\end{array}$ \\
\hline 3-phenylpropionaldehyde & & & & & 0.5 \\
\hline 6-Ethyl-5-hepten-2-one & 1.7 & & & & \\
\hline Acetate Cinnamic & & & & & 5.5 \\
\hline Camphene & & & & & 0.6 \\
\hline Caryophyllene & & 30.2 & & 5.3 & \\
\hline Caryophyllene oxide & & 2.8 & & 2.0 & \\
\hline Cis-Cinnamaldehyde & & & & & 0.6 \\
\hline Cis-Citral (neral) & 30.5 & & 33.3 & & \\
\hline Citronellal & & & 0.6 & & \\
\hline Eucalyptol & & 7.5 & & & 1.6 \\
\hline \multicolumn{6}{|l|}{ Eugenol } \\
\hline Geranial & 40.1 & & 45.4 & & \\
\hline Geraniol & 3.6 & & 3.4 & & \\
\hline Germancrene & 1.8 & & & & \\
\hline Styrene & & & & & 0.5 \\
\hline Terpinene-4 & & & & 2.3 & 0.6 \\
\hline Thujone & & 2.7 & & & \\
\hline Thymol & & 6.3 & 0.6 & 61.5 & \\
\hline Thymol methyl ether & & 3.4 & & & \\
\hline trans-Cinnamaldehyde & & & & & 86. \\
\hline$\alpha$-bergamotene & & & & 3.6 & \\
\hline$\alpha$-Caryophyllene & & & & 1.3 & \\
\hline$\alpha$-Limonene & 11.6 & & 1.3 & & 0.8 \\
\hline$\alpha$-Pinene & & & & & 1.8 \\
\hline$\alpha$-Terpinene & & 3.2 & & & 0.8 \\
\hline$\beta$-Limonene & & & 1.9 & 1.1 & \\
\hline$\beta$-Myrcene & & 5.3 & 13.4 & & \\
\hline$\beta$-Pinene & & & & 11.2 & 0.7 \\
\hline$\gamma$-Terpinene & 2.7 & 9.8 & & 10.2 & \\
\hline$p$-Cymene & 3.7 & 28.7 & 3.7 & & \\
\hline
\end{tabular}


as its main components; values similar to a study conducted using hydrodistillation and analyzed using gas chromatography (DA COSTA et al., 2010). The CzeyEO (true cinnamon) had trans-cinnamaldehyde $(86.0 \%)$ and cinnamic acetate $(5.4 \%)$ expressed at high concentrations, also similar those to described by ANDRADE et al. (ANDRADE et al., 2012).

Of the five analyzed EOs, it was observed that the oils from cinnamon (CzeyEO), rosemary pepper (LsidEO), Mexican mint (PambEO), and lemon grass (CcitEO) were able to inhibit the growth of $M$. tuberculosis. The MICs were $286.5 \mu \mathrm{g} / \mathrm{mL}$ $( \pm 130.2 \mu \mathrm{g} / \mathrm{mL})$ for CzeyEO, $299.5 \mu \mathrm{g} / \mathrm{mL}$ for LsidEO, $351.6 \mu \mathrm{g} / \mathrm{mL}( \pm 117.2 \mu \mathrm{g} / \mathrm{mL}), 351.6 \mu \mathrm{g} / \mathrm{mL}( \pm 39.1 \mu \mathrm{g} /$ $\mathrm{mL})$ for PambEO, and 1,250.0 $( \pm 0 \mu \mathrm{g} / \mathrm{mL})$ for CcitEO. Only the LalbEO, from bushy lippie, showed no antimycobacterial activity at the tested concentrations $(\mathrm{MIC}>1,250.0 \mu \mathrm{g} / \mathrm{mL})$. In this study, we interpreted antimycobacterial activity as inhibition at any value of MIC $\leq 1,250 \mu \mathrm{g} / \mathrm{mL}$, the highest test concentration.

The cinnamon, among all tested EOs, showed the highest inhibitory activity against $M$. tuberculosis, with a MIC of $286.5 \pm 130.2 \mu \mathrm{g} / \mathrm{mL}$. This result demonstrated its high antimycobacterial potential. A study conducted in Yaoundé, Cameroon demonstrated a MIC of $512 \mu \mathrm{g} / \mathrm{mL}$ using the EO from the leaves of C. zeylanicum (TEKWU et al., 2012). A previous report using the Cinnamomum verum plant, which also has trans-cinnamaldehyde as its major compound, demonstrated the inhibition of $M$. tuberculosis growth with a MIC of $12.5 \mu \mathrm{g} / \mathrm{mL}$ (ANDRADE-OCHOA et al., 2013). The main CzeyEO compounds, transcinnamaldehyde and cinnamic aldehyde, were also tested in a previous study (ANDRADE-OCHOA et al., 2015), and were active against $M$. tuberculosis with MICs of $3.12 \mu \mathrm{g} / \mathrm{mL}$ and $8.16 \mu \mathrm{g} / \mathrm{mL}$, respectively.

Several studies have reported that CzeyEO (cinnamon) showed a broad antibacterial activity, inhibiting the growth of $S$. aureus, L. monocytogenes, E. coli, $P$. aeruginosa (KIM et al., 2015), methicillin-resistant $S$. aureus (SINGH et al., 2012), S. cholerasuis, $B$. subtilis, $P$. vulgaris, and $K$. pneumoniae (PRABUSEENIVASAN et al., 2006).

A high antimycobacterial potential was also observed for LsidEO (rosemary pepper), which showed an MIC of $299.5 \pm 117.2 \mu \mathrm{g} / \mathrm{mL}$. There have been reports in the literature on its antibacterial activity against several bacterial species (VERAS et al., 2014; FREIRES et al., 2015b). However, there are no reports showing its capacity to inhibit $M$. tuberculosis growth.

In a study conducted by BUENO-SANCHEZ et al. (BUENO-SANCHEZ et al., 2009), using the $M$. tuberculosis $\mathrm{H} 37 \mathrm{Rv}$ strain, they obtained a MIC of
$400 \pm 120 \mu \mathrm{g} / \mathrm{mL}$ for the EO extracted from the leaves of Lippia origanoides, where caryophyllene (11.3\%) and $p$-cymene $(11.2 \%)$ were the main components, the same major compounds reported in the EO of rosemary pepper. $p$-cymene, another major compound in the aforementioned EO, was also tested alone against $M$. tuberculosis, with a MIC of $91.66 \mu \mathrm{g} / \mathrm{mL}$ (ANDRADE et al., 2012). Conversely, another study reported no inhibitory activity against $M$. tuberculosis for $p$-cymene at concentrations $<200 \mu \mathrm{g} / \mathrm{mL}$ (SANDOVALMONTEMAYOR et al., 2012).

PambEO (Mexican mint) showed antimycobacterial activity against the sensitive strain M. tuberculosis $\mathrm{H} 37 \mathrm{Rv}$ with a MIC of 351.6 $\pm 39.06 \mu \mathrm{g} /$ $\mathrm{mL}$. Antibacterial potential of PambEO was previously described against several bacteria, such as $S$. aureus (DA COSTA et al., 2010), methicillin-resistant $S$. aureus (GURGEL et al., 2009), E. coli, B. cereus (GALVAO RODRIGUES et al., 2013), and $K$. pneumoniae (GONÇALVES et al., 2012).

However, in a study conducted with eleven aromatic and medicinal plants occurring in Colombia (BUENO-SANCHEZ et al., 2009), growth inhibition activity was observed against $M$. tuberculosis $\mathrm{H} 37 \mathrm{Rv}$ by Lippia origanoides oil (thymol chemotype), with a MIC of $125 \mu \mathrm{g} / \mathrm{mL}$. The thymol compound, alone, had previously been demonstrated to inhibit the M. tuberculosis growth with a MIC of $0.78 \mu \mathrm{g} / \mathrm{mL}$ (ANDRADE-OCHOA et al., 2015). The antibacterial effects of carvacrol and thymol were previously attributed to their ability to permeabilize and depolarize the cytoplasmic membrane, increasing the levels of reactive oxygen species (ROS) and inducing membrane damage in bacteria (LI et al., 2014).

In our study, the EO of lemon grass (CcitEO) inhibited the M. tuberculosis at a concentration of $1,250 \mu \mathrm{g} / \mathrm{mL}$. Although, the value reported is higher than the MICs of other EOs in our study, this fact demonstrated its antimycobacterial potential. Moreover, there is no published report of its activity against $M$. tuberculosis. A previous study had demonstrated that the oil of $C$. citratus inhibits M. smegmatis growth (LEMOS et al., 1990). Several other reports demonstrated the antimicrobial activity of CcitEO against other gram-negative and grampositive bacteria (NAIK et al., 2010).

The chemical compound citral (geranial and neral) was the major compound reported in this EO. In a study using the extract of Citrus aurantifolia, the citral, alone, was able to inhibit M. tuberculosis H37Rv at a concentration of $50 \mu \mathrm{g} / \mathrm{mL}$, but no inhibition was seen against isoniazid- and rifampicin-resistant strains (SANDOVAL-MONTEMAYOR et al., 2012). Similar 
to carvacrol, citral causes oxidative damage to bacterial DNA by ROS formation (CHUECA et al., 2014).

The EO of bushy lippie did not show inhibitory activity against $M$. tuberculosis strain, with a MIC $>1,250 \mu \mathrm{g} / \mathrm{mL}$. However, other studies have reported its antimicrobial activity against other bacterial species (CRISTANI et al., 2007). However, few studies have reported a potential antimycobacterial activity of this EO.

The difference in antibacterial activity between the MIC results of EOs in this study and others reported in the literature may be due to differences in qualitative and quantitative composition of the EOs, the diluent agent, the reference culture, and the cell concentration. In addition, other factors can affect these constituents and influence the MIC including the geographical location, environment, incubation conditions, and stage of maturity (SWAMY et al., 2016; VAN DE VEL et al., 2017).

Some authors have considered that MICs $\leq 200 \mu \mathrm{g} / \mathrm{mL}$ for extracts and EOs indicate good activity against $M$. tuberculosis (TOSUN et al., 2004; ANDRADE-OCHOA et al., 2013; NGUTA et al., 2016). In addition, another study has indicated $\mathrm{MIC} \leq 512 \mu \mathrm{g} / \mathrm{mL}$ for EOs as a good candidate for studying new compounds with anti-M. tuberculosis activity (TEKWU et al., 2012).

The REMA microdilution method is a rapid, simple, and inexpensive technique for the detection of activity against $M$. tuberculosis isolates that can be used in low-income countries. The resazurin dye reduction results in an easily identified color change occurring at cell densities meaningful for MIC testing. Moreover, the dye reduction does not involve cellular uptake by the bacteria (MANN \& MARKHAM, 1998). Some differences in MIC values for the tested oils are explained by the fact that the experiments were conducted on different days, which resulted in the use of microorganisms with different growth days; although, exponential growth cultures were used in each case. These difficulties in MIC standardization were also observed in a study conducted in Louisiana, USA (FRANZBLAU et al., 1998). In addition, in order to disperse the natural clumping of the cells, vortexing of cultures was conducted prior inoculum; preparation technique is based on visual comparison between the turbidity of the bacterial suspension and the scale McFarland No. 1. Another important aspect is the hydrophobicity of the EO, a property that hinders homogenous mixing in the liquid media and may cause differences in microbial growth. In our study, Tween-80, a non-ionic surfactant and emulsifier, was added to all assays (BUENO-SANCHEZ et al., 2009). However, our study had a limitation: we did not measure the minimum bactericidal concentration, which corresponded to the minimum EO concentration that did not cause a color shift in cultures re-incubated in fresh medium.

M. tuberculosis has a high lipid content in the cell wall, which results in low permeability and resistance to some antimicrobial agents (FORRELLAD et al., 2013). Similarly, Gram-negative bacteria are also resistant to EOs in vitro, while Gram-positive bacteria are not. Gram-negative bacteria have an outer membrane rich in phospholipids, lipopolysaccharides, and proteins, resulting in resistance to EOs (RANA et al., 2011).

Due to the large number of components, EOs do not seem to have specific cell targets, working in different ways, and their antibacterial activity can be explained by the hydrophobicity of their components, which allows their interaction with bacterial membranes and penetration into the cell interior. The activity of some EOs, such as those with $p$-cymene, thymol, and citral at high concentrations, is associated with their capacity to cause structural and functional changes in the cytoplasmic membrane, resulting in the reduction of membrane potential and the loss of ATP and ions, in addition to possible interactions with intracellular targets. It is believed that the mechanism of action of trans-cinnamaldehyde involves lipid and protein damage, inhibition of bacterial cell division, as well as inhibition of enzymatic activities (ANDRADE et al., 2012).

\section{CONCLUSION}

In regards to potential antimycobacterial activity against the wild type $M$. tuberculosis H37Rv, we identified three EOs that have acceptable antituberculosis activity, LsidEO, CzeyEO, and PambEO (351.6 to $286.5 \mu \mathrm{g} / \mathrm{mL})$. The antimycobacterial activity of these tested EOs has not previously been reported and; therefore, our results can be evaluated as the first report on their antimycobacterial properties. These data confirmed the importance of bioprospecting studies for active substances showing antimycobacterial action, which are still scarce. In order to seek new therapies for TB, future studies are needed to assess the effects of the association between these EOs and the first-line drugs used in treatment.

\section{ACKNOWLEDGMENTS}

The authors gratefully acknowledge the support of the Prisco Bezerra Herbarium, at the Department of Biology of the Universidade Federal do Ceará. 


\section{CONFLICT OF INTEREST}

No potential conflict of interest was reported by the authors.

\section{REFERENCES}

ADAMS, R. Identification of essential oils components by gas chromatography/quadrupole mass spectroscopy. 3rd. Illinois, USA: Allured Publishing Corporation, 2001. ISBN 978-0-9981557-2-2. Available from: <http://www.juniperus.org/uploads/2/2/6/3/22639912/bk4frontisbnpreface-contents5thedonline2017.pdf $>$. Acessed: Feb. 18, 2018.

ANDRADE-OCHOA, S. et al. Evaluation of antimycobacterium activity of the essential oils of cumin (Cuminum cyminum), clove (Eugenia caryophyllata), cinnamon (Cinnamomum verum), laurel (Laurus nobilis) and anis (Pimpinella anisum) against Mycobacterium tuberculosis. Advances in Biological Chemistry, v. 3, n. 5, p. 4, 2013. Available from: $<$ http://www.scirp.org/journal/abc/>. Accessed: Feb. 18, 2018. doi: 10.4236/abc.2013.35052.

ANDRADE-OCHOA, S. et al. Quantitative structure-activity relationship of molecules constituent of different essential oils with antimycobacterial activity against Mycobacterium tuberculosis and Mycobacterium bovis. BMC Complement Altern Med, v. 15, p. 332, 2015. Available from: <https://bmccomplementalternmed. biomedcentral.com/articles/10.1186/s12906-015-0858-2>. Accessed: Feb. 18, 2018. doi: 10.1186/s12906-015-0858-2.

ANDRADE, M.A. et al. Óleos essenciais de Cymbopogon nardus, Cinnamomum zeylanicum e Zingiber officinale: composição, atividades antioxidante e antibacteriana. Revista Ciência Agronômica, v. 43, n. 2, p. 9, 2012. Available from: <http://www.redalyc.org/ html/1953/195321143025/>. Accessed: Feb. 18, 2018.

BUENO-SANCHEZ, J.G. et al. Anti-tubercular activity of eleven aromatic and medicinal plants occurring in Colombia. Biomedica, v. 29, n. 1, p. 51-60, 2009. Available from: <https://www.ncbi.nlm. nih.gov/pubmed/19753839>. Accessed: Feb. 18, 2018.

CHUECA, B. et al. Oxygenated monoterpenes citral and carvacrol cause oxidative damage in Escherichia coli without the involvement of tricarboxylic acid cycle and Fenton reaction. Int J Food Microbiol, v. 189, p. 126-31, 2014. Available from: <https://www.ncbi.nlm.nih. gov/pubmed/25146464> . Accessed: Feb. 18, 2018. doi: 10.1016/j. ijfoodmicro.2014.08.008.

CRAVEIRO, A.A. et al. A simple and inexpensive steam generator for essential oils extraction. Jounal of Chemical Education, v. 53, n. 10, p. 1, 1976. Available from: <https://pubs.acs.org/doi/abs/10.1021/ ed053p652? journalCode=jceda8 $>$. Accessed: Feb. 18, 2018. doi: 10.1021/ed053p652.

CRISTANI, M. et al. Interaction of four monoterpenes contained in essential oils with model membranes: implications for their antibacterial activity. J Agric Food Chem, v. 55, n. 15, p. 6300-8, 2007. Available from: <https:/www.ncbi.nlm.nih.gov/ pubmed/17602646>. Accessed: Feb. 18, 2018. doi: 10.1021/ jf070094x.

DA COSTA, J.G.M. et al. Chemical Composition, Antibacterial and Fungicidal Activities of Leaf Oil of Plectranthus amboinicus (Lour.) Spreng. Journal of Essential Oil Research, v. 22, n. 2, p. 3, 2010. Available from: <http://www.tandfonline.com/doi/abs/ 10.1080/10412905.2010.9700298>. Accessed: Feb. 18, 2018. doi: 10.1080/10412905.2010.9700298.
FORRELLAD, M.A. et al. Virulence factors of the Mycobacterium tuberculosis complex. Virulence, v. 4, n. 1, p. 3-66, 2013. Available from: $<$ https://www.ncbi.nlm.nih.gov/pubmed/23076359>. Accessed: Feb. 18, 2018. doi: 10.4161/viru.22329.

FRANZBLAU, S.G. et al. Rapid, low-technology MIC determination with clinical Mycobacterium tuberculosis isolates by using the microplate Alamar Blue assay. J Clin Microbiol, v. 36, n. 2, p. 362-6, 1998. Available from: <https://www.ncbi.nlm.nih.gov/ pubmed/9466742>. Accessed: Feb. 18, 2018.

FREIRES, I.A. et al. The Effect of Essential Oils and Bioactive Fractions on Streptococcus mutans and Candida albicans Biofilms: A Confocal Analysis. Evid Based Complement Alternat Med, v. 2015 , p. 871316,2015 a. Available from: <https://www.hindawi. com/journals/ecam/2015/871316/>. Accessed: Feb. 18, 2018. doi: $10.1155 / 2015 / 871316$

FREIRES, I.A. et al. Antibacterial Activity of Essential Oils and Their Isolated Constituents against Cariogenic Bacteria: A Systematic Review. Molecules, v. 20, n. 4, p. 7329-58, 2015b. Available from: $<$ https://www.ncbi.nlm.nih.gov/pubmed/25911964>. Accessed: Feb. 18, 2018. doi: 10.3390/molecules20047329.

GALVAO RODRIGUES, F.F. et al. Study of the Interference between Plectranthus species Essential Oils from Brazil and Aminoglycosides. Evid Based Complement Alternat Med, v. 2013, p. 724161, 2013. Available from: <https://www.ncbi.nlm.nih.gov/pubmed/23662150>. Accessed: Feb. 18, 2018. doi: 10.1155/2013/724161.

GANIHIGAMA, D.U. et al. Antimycobacterial activity of natural products and synthetic agents: Pyrrolodiquinolines and vermelhotin as anti-tubercular leads against clinical multidrug resistant isolates of Mycobacterium tuberculosis. European Journal of Medicinal Chemistry, v. 89 , p. 1-12, 2015. Available from: <http://www. sciencedirect.com/science/article/pii/S0223523414009532>. Accessed: Feb. 18, 2018. doi: 10.1016/j.ejmech.2014.10.026.

GAONKAR, R. et al. Development and validation of reverse phase high performance liquid chromatography for citral analysis from essential oils. J Chromatogr B Analyt Technol Biomed Life Sci, v. 1036-1037, p. 50-56, 2016. Available from: $<$ https://www.ncbi.nlm. nih.gov/pubmed/27710890>. Accessed: Feb. 18, 2018. doi: 10.1016/j. jchromb.2016.10.001.

GONÇALVES, T.B. et al. Effect of subinihibitory and inhibitory concentrations of Plectranthus amboinicus (Lour.) Spreng essential oil on Klebsiella pneumoniae. Phytomedicine, v. 19, n. 11, p. 962-8, 2012. Available from: <https://www.ncbi.nlm.nih.gov/pubmed/22776104>. Accessed: Feb. 18, 2018. doi: 10.1016/j.phymed.2012.05.013.

GURGEL, A.P.A.D. et al. Antibacterial Effects of Plectranthus amboinicus (Lour.) Spreng (Lamiaceae) in Methicillin Resistant Staphylococcus aureus (MRSA). Latin American Journal of Pharmacy, v. 28, n. 3, p. 5, 2009. Available from: <http://www.latamjpharm. org/trabajos/28/3/LAJOP_28_3_2_3_HSI8QF4I6P.pdf $>$. Accessed: Feb. 18, 2018

INMET. Instituto Nacional de Metereologia. Brasilia-DF, 2018. Online. Available from: <http://www.inmet.gov.br/portal/>. Accessed: Fev. 18, 2018

KIM, Y.G. et al. Cinnamon bark oil and its components inhibit biofilm formation and toxin production. Int J Food Microbiol, v. 195, p. 30-9, 2015. Available from: $<$ https://www.ncbi.nlm.nih.gov/pubmed/25500277>. Accessed: Feb. 18, 2018. doi: 10.1016/j.jffoodmicro.2014.11.028. 
LEMOS, T.L.G. et al.Antimicrobial activity of essential oils of Brazilian plants. Phytotherapy Research, v. 4, n. 2, p. 3, 1990. Available from $<$ https://onlinelibrary.wiley.com/doi/abs/10.1002/ptr.2650040210>. Accessed: Feb. 18, 2018. doi: 10.1002/ptr.2650040210

LI, H. et al. Antibacterial activity and mechanism of action of Monarda punctata essential oil and its main components against common bacterial pathogens in respiratory tract. Int J Clin Exp Pathol, v. 7, n. 11, p. 7389-98, 2014. Available from: <https://www. ncbi.nlm.nih.gov/pubmed/25550774>. Accessed: Feb. 18, 2018.

MACHADO, T.F .et al. The antimicrobial efficacy of Lippia alba essential oil and its interaction with food ingredients. Brazilian Journal of Microbiology, v. 45, n. 2, p. 699-705, 2014. Available from: <http://www.ncbi.nlm.nih.gov/pmc/articles/PMC4166302/>. Accessed: Feb. 18, 2018. doi: 10.1590/S1517-83822014000200045.

MANN, C.M; MARKHAM, J.L. A new method for determining the minimum inhibitory concentration of essential oils. J Appl Microbiol, v. 84, n. 4, p. 538-44, 1998. Available from: <http://onlinelibrary.wiley. com/doi/10.1046/j.1365-2672.1998.00379.x/full>. Accessed: Feb. 18, 2018. doi: 10.1046/j.1365-2672.1998.00379.x.

MARCHESE, A. et al. Antibacterial and antifungal activities of thymol A brief review of the literature. Food Chem, v. 210, p. 402-14, 2016. Available from: <https://www.ncbi.nlm.nih.gov/pubmed/27211664>. Accessed: Feb. 18, 2018. doi: 10.1016/j.foodchem.2016.04.111.

MENDES, L.S.S. Estudo químico e atividade larvicida frentea ao Aedes aegypti do óleo essencial das folhas de Cinnamomum zeylanicum Breyn (canela). 2011. 71f. Dissertation (Master in Chemistry) - Course of Chemistry, Federal University of Maranhão.

MIGLIORI, G.B. et al. tuberculosis in South Africa: old questions, new answers. Lancet, v. 375, n. 9728, p. 1760-1, 2010. Available from: $<$ https://www.ncbi.nlm.nih.gov/pubmed/20488526>. Accessed: Feb. 18, 2018. doi: 10.1016/S0140-6736(10)60593-4.

MIRANDA, V. et al. Evaluation of the effect of time of cutting on the content of the essential oil of the holy grass (Cymbopogon citratus (DC) Stapf). Journal of Biotechnology and Biodiversity, v. 4, n. 1, p. 55-59, 2013. Available from: $<$ https://sistemas.uft.edu.br/periodicos/ index.php/JBB/article/download/430/285/>. Accessed: Feb. 18, 2018.

MOHAMAD, S. et al. Antituberculosis activity, phytochemical identification of Costus speciosus (J. Koenig) Sm., Cymbopogon citratus (DC. Ex Nees) Stapf., and Tabernaemontana coronaria (L.) Willd. and their effects on the growth kinetics and cellular integrity of Mycobacterium tuberculosis H37Rv. BMC Complement Altern Med, v. 18, n. 1, p. 5, 2018. Available from: $<$ https://bmccomplementalternmed.biomedcentral com/articles/10.1186/s12906-017-2077-5>. Accessed: Feb. 18, 2018. doi: $10.1186 /$ s12906-017-2077-5.

NAIK, M.I. et al. Antibacterial activity of lemongrass (Cymbopogon citratus) oil against some selected pathogenic bacterias. Asian Pacific Journal of Tropical Medicine, v. 3, n. 7, p. 4, 2010 Available from: <https://www.sciencedirect.com/science/article/pii/ S1995764510601290>. Accessed: Feb. 18, 2018. doi: 10.1016/S19957645(10)60129-0.

NASCIMENTO, G.F.L. et al. Antibacterial activity of plant extracts and phytochemicals on antibiotic-resistant bacteria. Brazilian Journal of Microbiology, v. 31, n. 4, p. 5, 2000. Available from: <http://www. scielo.br/scielo.php?pid=S1517-83822000000400003\&script $=$ sci arttext\&tlng-pt>. Accessed: Feb. 18, 2018. doi: 10.1590/S151783822000000400003
NEWMAN, D.J. et al. Natural products as sources of new drugs over the period 1981-2002. J Nat Prod, v. 66, n. 7, p. 1022-37, 2003. Available from: $<$ https://www.ncbi.nlm.nih.gov/pubmed/12880330>. Accessed: Feb. 18, 2018. doi: 10.1021/np0300961.

NGUTA, J.M. et al. Antimycobacterial and cytotoxic activity of selected medicinal plant extracts. J Ethnopharmacol, v. 182, p. 105, 2016. Available from: <https://www.sciencedirect.com/science/ article/pii/S037887411630054X>. Accessed: Feb. 18, 2018. doi: 10.1016/j.jep.2016.02.010.

NUNES, R. et al. Caracterização da Lippia sidoides Cham (Verbenaceae) como matéria-prima vegetal para uso em produtos farmacêuticos. Scientia Plena, v. 1, n. 7, 2005. Available from: $<$ https://scientiaplena. emnuvens.com.br/sp/article/view/585>. Accessed: Feb. 18, 2018.

OLADIMEJI, F. et al. Effect of autoxidation on the composition and antimicrobial activity of essential oil of Lippia multiflora. Pharmaceutical and Pharmacological Letters, v. 11, n. 2, p. 64-67, 2001. Accessed: Feb. 18, 2018.

PALOMINO, J.C. et al. Resazurin microtiter assay plate: simple and inexpensive method for detection of drug resistance in Mycobacterium tuberculosis. Antimicrob Agents Chemother, v. 46, n. 8, p. 2720-2, 2002. Available from: <https://www.ncbi.nlm.nih.gov/pubmed/12121966>. Accessed: Feb. 18, 2018. doi: 10.1128/AAC.46.8.2720-2722.2002.

PARANAGAMA, P. et al. A comparison of essential oil constituents of bark, leaf, root and fruit of cinnamon (Cinnamomum zeylanicum Blum) grown in Sri Lanka. Journal of the National Science Foundation of Sri Lanka, v. 29, n. 3-4, 2001. Available from: <https://jnsfsl.sljol. info/articles/abstract/10.4038/jnsfsr.v29i3-4.2613/>. Accessed: Feb. 18, 2018. doi: 10.4038/jnsfsr.v29i3-4.2613.

PRABUSEENIVASAN, $\mathrm{S}$. et al. In vitro antibacterial activity of some plant essential oils. BMC Complement Altern Med, v. 6, p. 39, 2006. Available from: $<$ https://www.ncbi.nlm.nih.gov/pubmed/17134518>. Accessed: Feb. 18, 2018. doi: 10.1186/1472-6882-6-39.

RANA, I.S. et al. In vitro study of antibacterial activity of aromatic and medicinal plants essential oils with special reference to cinnamon oil. International Journal of Pharmacy and Pharmaceutical Sciences, v. 3, n. 4, p. 5, 2011. Available from: <http://www. ijppsjournal.com/Vol3Issue4/2686.pdf>. Accessed: Feb. 18, 2018.

RODRIGUES, G. et al. Study of the interference between Plectranthus species essential oils from Brazil and aminoglycosides. Evidence-Based Complementary and Alternative Medicine, v. 2013, 2013. Available from: <https://www.hindawi.com/journals/ecam/2013/724161/abs/>. Accessed: Feb. 18, 2018. doi: 10.1155/2013/724161.

SANDOVAL-MONTEMAYOR, N.E. et al. Chemical composition of hexane extract of Citrus aurantifolia and anti-Mycobacterium tuberculosis activity of some of its constituents. Molecules, v. 17, n. 9, p. 11173-84, 2012. Available from: <https://www.ncbi.nlm.nih. gov/pubmed/22992784>. Accessed: Feb. 18, 2018. doi: 10.3390/ molecules170911173.

SCHUCK, V.J. et al. Avaliação da atividade antimicrobiana de Cymbopogon citratus. RBCF, Rev. bras. ciênc. farm.(Impr.), v. 37, n. 1, p. 45-49, 2001. Accessed: Feb. 18, 2018.

SINGH, S. et al. Rapid Identification and Drug Susceptibility Testing of Mycobacterium tuberculosis: Standard Operating Procedure for Non-Commercial Assays: Part 3: Colorimetric Redox Indicator Assay v1.3.12. J Lab Physicians, v. 4, n. 2, p. 120-6, 2012. Available from: 
$<$ https://www.ncbi.nlm.nih.gov/pubmed/23440615>. Accessed: Feb. 18, 2018. doi: 10.4103/0974-2727.105594

SURERAM, S. etal.Antimycobacterial activity of bisbenzylisoquinoline alkaloids from Tiliacora triandra against multidrug-resistant isolates of Mycobacterium tuberculosis. Bioorganic \& Medicinal Chemistry Letters, v. 22, n. 8, p. 2902-2905, 2012. Available from: <http:// www.sciencedirect.com/science/article/pii/S0960894X12002454>. Accessed: Feb. 18, 2018. doi: 10.1016/j.bmcl.2012.02.053.

SWAMY, M.K. et al. Antimicrobial Properties of Plant Essential Oils against Human Pathogens and Their Mode of Action: An Updated Review. Evidence-based Complementary and Alternative Medicine : eCAM, v. 2016, p. 3012462, 2016. Available from: <http:// www.ncbi.nlm.nih.gov/pmc/articles/PMC5206475/>. Accessed: Feb. 18, 2018. doi: 10.1155/2016/3012462.

TAVARES, E.S. et al. Análise do óleo essencial de folhas de três quimiotipos de Lippia alba (Mill.) N. E. Br. (Verbenaceae) cultivados em condições semelhantes. Brazilian Journal of Pharmacognosy, v. 15 , n. 1, p. 5, 2005. Available from: <http://www.scielo.br/ scielo.php?script $=$ sci arttext\&pid $=\mathrm{S} 0102-695 \mathrm{X} 2005000100002>$. Accessed: Feb. 18, 2018. doi: 10.1590/S0102-695X2005000100002.

TEKWU, E.M. et al. Antibacterial activity of selected Cameroonian dietary spices ethno-medically used against strains of Mycobacterium tuberculosis. J Ethnopharmacol, v. 142, n. 2, p. 374-82, 2012. Available from: <https://www.sciencedirect.com/science/article/pii/ S0378874112002966?via\%3Dihub>. Accessed: Feb. 18, 2018. doi: 10.1016/j.jep.2012.05.003.

TOSUN, F. et al. Antimycobacterial screening of some Turkish plants. J Ethnopharmacol, v. 95, n. 2-3, p. 273-5, 2004. Available from: $<$ https://
www.sciencedirect.com/science/article/pii/S0378874104003654>. Accessed: Feb. 18, 2018. doi: 10.1016/j.jep.2004.07.011.

VAN DE VEL, E. et al. A review on influencing factors on the minimum inhibitory concentration of essential oils. Crit Rev Food Sci Nutr, p. 1-22, 2017. Available from: <http://www.tandfonline.com/ doi/abs/10.1080/10408398.2017.1371112>. Accessed: Feb. 18, 2018. doi: 10.1080/10408398.2017.1371112.

VASCONCELOS, S. et al. Plectranthus amboinicus essential oil and carvacrol bioactive against planktonic and biofilm of oxacillin- and vancomycin-resistant Staphylococcus aureus. BMC Complement Altern Med, v. 17, n. 1, p. 462, 2017. Available from: <https:// bmccomplementalternmed.biomedcentral.com/articles/10.1186/ s12906-017-1968-9>. Accessed: Feb. 18, 2018. doi: 10.1186/s12906017-1968-9.

VERAS, H.N. et al. Antimicrobial effect of Lippia sidoides and thymol on Enterococcus faecalis biofilm of the bacterium isolated from root canals. ScientificWorldJournal, v. 2014, p. 471580, 2014. Available from: <https://www.ncbi.nlm.nih.gov/pubmed/24683344>. Accessed: Feb. 18, 2018. doi: 10.1155/2014/471580.

WHO. Global tuberculosis report 2017. In: ORGANIZATION, W. H (Ed.). Global tuberculosis report 2017, 2017. Online. Available from: $<$ http://www.who.int/tb/publications/global_report/en/>. Accessed: 18 fev. 2018.

WIWATTANARATTANABUT, K.et al. In Vitro Anti-Cariogenic Plaque Effects of Essential Oils Extracted from Culinary Herbs. J Clin Diagn Res, v. 11, n. 9, p. Dc30-dc35, 2017. Available from: <https:// www.ncbi.nlm.nih.gov/pmc/articles/PMC5713730/pdf/jcdr-11-DC30. pdf $>$. Accessed: Feb. 18, 2018. doi: 10.7860/jcdr/2017/28327.10668. 